\title{
P020: Multiresistant bacteria in positive urocultures in a Dakar university hospital (Senegal)
}

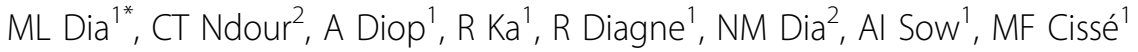 \\ From 2nd International Conference on Prevention and Infection Control (ICPIC 2013) \\ Geneva, Switzerland. 25-28 June 2013
}

\section{Introduction}

Multiresistant bacteria in urines are often associated with nosocomial infections.

\section{Objectives}

The aim of this study was to determine the proportion of multiresistant bacteria in positive urocultures in the Teaching Hospital of Fann.

\section{Methods}

This study was made on data recorded from registers of bacteriological laboratory between $1^{\text {st }}$ January 2008 and 31 December 2011.

\section{Results}

Three hundred and nine multiresistant bacteria (309) among the 709 mutiresistant strains were isolated from urines $(43,58 \%)$. The mean age was 39,73 years [range $=1-83$ ] with a sex ratio of 0.88 . Most of the patients were hospitalized $(62,5 \%)$. The infectious diseases clinic provided most of the multiresistant bacteria $(41,1 \%)$, followed by the neurology department $(14,24 \%)$ and paediatrics department (12,23\%). The majority of multiresistant bacteria were constituted by extended spectrum betalactamase enterobacteriaceae $(86,08 \%)$ and Acinetobacter spp (5, $50 \%)$. E. coli were the most frequent bacteria $(35,92 \%)$ followed by Klebsiella pneumoniae $(35,60)$. Enterobacteriaceae were susceptible to imipenem, amikacin and colistin but were resistant to quinolones and other aminosides. Methicillin-resistant Staphylococcus aureus and methicillin-resistant Staphylococcus saprophyticus were susceptible to vancomycin. Strains of Acinetobacter were susceptible to imipemem and colistin.

${ }^{1}$ Laboratory of Bacteriology-Virology, CHU of Fann, Dakar, Senegal

Full list of author information is available at the end of the article

\section{Conclusion}

Most of the multiresistant bacteria in the teaching hospital of Fann are isolated from urines. That's why it is important to insist on prevention by respecting hygiene measures during invasive gestures like pose of urinary catheters.

\section{Disclosure of interest}

None declared.

\section{Author details}

${ }^{1}$ Laboratory of Bacteriology-Virology, CHU of Fann, Dakar, Senegal.

${ }^{2}$ Infectious diseases department, CHU of Fann, Dakar, Senegal.

Published: 20 June 2013

\section{doi:10.1186/2047-2994-2-S1-P20}

Cite this article as: Dia et al:: P020: Multiresistant bacteria in positive urocultures in a Dakar university hospital (Senegal). Antimicrobial Resistance and Infection Control 2013 2(Suppl 1):P20.
Submit your next manuscript to BioMed Central and take full advantage of:

- Convenient online submission

- Thorough peer review

- No space constraints or color figure charges

- Immediate publication on acceptance

- Inclusion in PubMed, CAS, Scopus and Google Scholar

- Research which is freely available for redistribution
() Biomed Central
C Biomed Central

(0) 2013 Dia et al; licensee BioMed Central Ltd. This is an Open Access article distributed under the terms of the Creative Commons Attribution License (http://creativecommons.org/licenses/by/2.0), which permits unrestricted use, distribution, and reproduction in any medium, provided the original work is properly cited. 